\title{
The Inclusive Education Model of MTs Yaketunis Yogyakarta
}

\author{
Sumarni ${ }^{1}$, Farida Hanun ${ }^{2}$, Wahid Khozin ${ }^{3}$, Opik Abdurrahman Taufik ${ }^{4}$, \\ Iyoh Mastiyah $^{5}$, Elma Hariyani ${ }^{6}$, Abdul Kadir Ahmad ${ }^{7}$ \\ \{marni_ch@yahoo.com.au ${ }^{1}$, hanunjkt@gmail.com ${ }^{2}$,wah_zinmi@yahoo.com ${ }^{3}$, \\ taufikrachman74@gmail.com ${ }^{4}$, mastiyah9@gmail.com ${ }^{5}, \overline{\text { elmaharyani@kemenag.go.id }}^{6}$, \\ abduladir76@gmail.com ${ }^{7}$
}

Research \& Development and Training Agency, MoRA ${ }^{1,2,3,4,5,6,7}$

\begin{abstract}
This study aimed to determine how the inclusive education model held by MTs Yaketunis. This research used a qualitative approach. Data collection techniques used interview guidelines, observation and documentation study. The respondents were the head of the foundation, the head of the madrasah, teachers, employees, students, and the madrasah committee. Data were analyzed using qualitative descriptive techniques. The results of this study indicated that the education service model at MTs Yaketunis was like a general boarding school. The process of learning in this madrasa was the same as in madrasas in general, but there were modifications to the curriculum. The implementation of inclusive education at MTs Yaketunis ran quite well despite there were any obstacles, especially in learning infrastructure, special tutor teachers and limited funds. These obstacles did not hinder the teacher creativity to improve the quality of their children's education. They had spirit to work hard, patience, and sincerity to teach them. It was one of the assets for the success. This was proven by the various achievements made by MTs Yaketunis students.
\end{abstract}

Keywords: Model, Inclusive Education, MTs Yaketunis

\section{Introduction}

Education is a need of every human being in life, as a conscious human effort to develop his potential through a learning process and / or other means that are known and recognized by society. Article 31 paragraph (1) of the 1945 Constitution of the Republic of Indonesia states that every citizen has the right to education, and paragraph (3) emphasizes that the government strives for and implements a National Education system that enhances faith and devotion as well as noble morals in order to educate life nation regulated in law. Therefore, all components of the nation are obliged to educate the nation's life which is one of the goals of the Indonesian state.

The National Education System Law (Law No.20 of 2003) article 32 also states that "Special education means education for students who have a difficulty level in following the learning process due to physical, emotional, and mental disorders, and social and/or have the potential for intelligence and special talents. "The government has guaranteed education for children with special needs in the law in order to get an education like any other normal child. This law is a juridical basis that provides equal rights in obtaining adequate education services for all the special children. There will no longer be any difference in terms of education for special children.

One of the efforts to fulfill the rights of children with special needs is by organizing special education services (inclusive education). To manage inclusive education, several conditions are needed that can ensure the smooth running of inclusive education, namely the 
availability of facilities, accessibility of services for children with special needs, special tutor teachers and the existence of supporting services or the Inclusive Education Resource Center. According to data from the Yogyakarta City Education Office, currently there are 67 public and private inclusive schools consisting of 7 Kindergartens, 47 Elementary School (SD) SD and 17 Junior High School (SMP) levels.

One of the educational institutions that provides services for students with special needs is MTs Yaketunis, which is under the Islamic Blind Welfare Foundation (Yaketunis) in Yogyakarta City. This foundation only develops special education for children with visual impairments, both totally and partly blind (low vision). This foundation has two educational institutions which include SLB A Yaketunis for elementary school level and MTs Yaketunis for the first secondary level which is a transformation from MTs LB / A Yaketunis. Yaketunis was the first foundation to support people with Islamic visual impairment and became the first center for the study and dissemination of the Braille Alquran in Indonesia. This preaching started in the 1960s, namely reading the Alquran published by Jordan and Pakistan. Yaketunis also has a history of being the first publisher of a Braille Alquran that conforms to the international Braille Alquran writing standards. Every year around 250 sets of Alquran Braille are published by Yaketunis, and sent to blind institutions throughout Indonesia, including to Malaysia.

In addition to providing educational facilities, religious activities, and a Braille book library which reaches 1,500 titles, MTs Yaketunis students are also facilitated to develop their talents in the sports field. Some achievement was achieved by them, like the sports champion at the provincial and national level, Mathematics Olympiad champion, and other champions that coloring the history of this Islamic institution. In addition, they continue to pursue higher education and are able to compete with normal students. At Madrasah Aliyah Negeri 5 Maguwoharjo Sleman, for example, they generally have a rank of 1 to 7 .

From the description above, it can be concluded that Yaketunis has a great contribution, especially in increasing the dignity of Muslim blind children. The education given to blind children at MTs Yaketunis in particular has led them to become children who are confident, independent, and have abilities that are not inferior to other normal children in both academic and non-academic fields. On that basis, it is necessary to study how the education service model for blind children at MTs Yaketunis.

\section{Theory Study}

\section{Definition of Children with Special Needs}

There are several terms used to indicate the situation of children with special needs. The term children with special needs is a translation of child with special needs which has been widely used internationally. There are several other terms that have been used, including children with disabilities, children with disabilities, children with disabilities, children with deviations, and extraordinary children. There is one term that has been widely used, namely diffable, which actually stands for difference ability (Purwanto, 2015).

Children with special needs (special needs children) can also be interpreted in a simple way, namely as children who are slow (slow) or experiencing disorders (retarded) who will never succeed in school as children in general. Many terms are used as variations of special needs, such as disability, impairment, and handicaped. According to the World Health Organization (WHO), the definition of each term is as follows:

1. Impairment: is a condition or condition in which individuals experience loss or abnormality of psychological, physiological or anatomical structure functions in general at the organ level. For example, someone who has an amputation of one leg has a leg disability. 
2. Disability: is a condition in which the individual experiences disabilities that are possible due to impairments such as disabilities in body organs. For example, in a person with a leg disability, then he will feel the reduced leg function to perform mobility.

3. Handicaped: is an individual's disadvantage resulting from impairment or disability that limits or hinders the fulfillment of normal roles for the individual. Handicaped can also be defined as a situation in which individuals experience an inability to socialize and interact with the environment. This is possible due to abnormalities and reduced function of individual organs. An example of a person who has a leg amputation so that for mobility activities or interacting with the environment he needs a wheelchair.

The Indonesian Blind Association (PERTUNI, 2004) defines blind people as people who have no vision at all (totally blind) so that they still have residual vision and are still unable to use their eyesight to read ordinary writing measuring 12 points in normal light even though they are assisted with glasses ( less alert). In this case, what is meant by 12 points is the standard font size on a computer where the 1 inch wide field contains 12 letters. However, this should not be interpreted that letters with a size of 18 points, for example, on a 1 inch wide area contains 18 letters. Blind people who still have residual functional vision are referred to as "less alert" people or better known as "low vision".

Children with special needs are also defined as individuals who have different characteristics from other individuals who are considered normal by society in general. More specifically, children with special needs show physical, intellectual, and emotional characteristics that are lower or higher than normal children of their peers or are outside the normal standards prevailing in society. They experience difficulties in achieving success both in terms of social, personal, and educational activities (Bachri, 2010).

Based on some of the definitions above, what is meant by Children with Special Needs is an individual who has physical, intellectual, mental or emotional limitations, above or below the average individual in general.

\section{Types of Children with Special Needs}

PP No. 17 of 2010 Article 129 paragraph (3) stipulates that students with disabilities consist of students who are: blind, deaf, speech impaired, mentally retarded, mentally disabled, disabled, have learning difficulties, are slow to learn, autistic, have motor problems, are victims of narcotics abuse (prohibited substances and other addictive substances), and have other disorders. In this study, students with disabilities or children with special needs are special children with visual impairments (blind).

Blind people are individuals who have visual impairments. Blindness can be classified into two groups, namely: total blindness (blind) and low vision (low vision). The definition of visual impairment according to Kaufman \& Hallahan (1991) is an individual who has visual impairment or vision accuracy of less than $6 / 60$ after being corrected or no longer has vision. Because blind people have limitations in the sense of sight, the learning process emphasizes other senses, namely the sense of touch and the sense of hearing. Therefore, the principle that must be considered in teaching blind individuals is that the media used must be tactual and sound, for example the use of braille writing, embossed pictures, model objects and real objects. Meanwhile, the voice media are voice recorder and JAWS software. To help visually impaired activities in special schools they learn about Orientation and Mobility. Orientation and Mobility include learning how the blind know the place and direction and how to use a white stick (a special stick for the blind made of aluminum).

\section{Inclusive Education service model}


Children with special needs are a substitute for the term disabled or disabled children. Actually, the term Children with Special Needs refers to those who have physical, emotional, mental, intellectual and / or social disabilities. Included in children with special needs include: blind, deaf, mentally retarded, disabled, disabled, learning difficulties, behavior disorders, gifted children, and children with health problems. Because of the characteristics and constraints they have, they need a form of special education services that are tailored to their abilities and potential.

According to Hallahan and Kauffman (1991), there are various options for providing education for children with special needs, namely:

1. Regular Class Only (Regular class with regular teachers)

2. Regular Class with Consultation (Regular class with special education teacher consultants)

3. Itinerant Teacher (Regular class with visiting teachers)

4. Resource Teacher (Source teacher, namely a normal class with an ordinary teacher, but on several occasions the child is in the resource room with the source teacher)

5. Diagnostic-Prescriptive Center

6. Hospital or Homebound Instruction (Education at home or in the hospital, which is a condition that allows children not to enter regular school).

7. Self-contained Class (special classes in ordinary schools with special education teachers)

8. Special Day School (special school without boarding)

9. Residential School (Special school boarding)

Meanwhile, Samuel A. Kirk (1986) made a gradation of education services for children with special needs, graded from a segregation model to a mainstreaming model. The forms of education services for children with special needs can be grouped into 2 major groups, namely: Segregated Forms of Education Services and Integrated/Integrated Education Services. Segregated Form of Education Service is an education system that is separate from the normal children's education system. Education for children with special needs through the segregation system means the provision of education that is carried out specifically, and is separate from the provision of education for normal children. In other words, children with special needs are provided with educational services at special educational institutions for children with special needs such as Special Schools or Extraordinary Elementary Schools, Extraordinary Junior High Schools, Special High Schools. Meanwhile, the form of integrated/ integrated education services is an education system that provides opportunities for children with special needs to study together with normal children to learn under one roof. The integrated education system is also called the integrated education system, which is an education system that brings children with special needs to an atmosphere of integration with normal children. The integration can be comprehensive, partly, integrated in the context of socialization. The integrated model was used in this madrasa.

\section{Learning Strategies for Blind Children}

The problem of learning strategies in the education of blind children is based on two thoughts. On the one hand, how to modify the environment to suit the child's condition and on the other hand, how to make optimal use of the senses that are still functioning, to compensate for weakness caused by loss of visual function. The learning strategy in the education of blind children is essentially a general learning strategy that is applied in the framework of the two thoughts above. However, in learning blind children there are principles that must be considered, including: individual, concrete/sensory experience, totality, independent activities, and learning patterns. 


\section{Previous Studies}

There are many studies that have been done regarding children with special needs, especially at MTs Yaketunis Yogyakarta. Various studies that have been conducted have focused on different problems, such as:Problematika Pembelajaran Qira'ah di MTs Yaketunis Yogyakarta (Tinjauan segi non linguistik) (Ahmad Qory Mubarak, 2009); Uji Coba Pembelajaran Dengan Pendekatan PMRI Pada Siswa Tunanetra Kelas VIII MTs Yaketunis Yogyakarta Dan Hasil Belajar Siswa Dalam Materi Fungsi (Hanjani, Maria Karina Metta, 2010); Pembelajaran Bahasa Arab Siswa Tunanetra Kelas VIII MTs Yaketunis Yogyakarta (Saputri Dwi Astuti, 2011); Implementasi Media Braille Dalam Pembelajaran Bahasa Arab Di Kelas VIII MTs Yaketunis Yogyakarta Tahun Ajaran 2014/2015 (Desty Prasetyaningtyas, 2014); Penggunaan Media Pembelajaran Bahasa Arab Pada Siswa Tunanetra Di MTs Yaketunis Yogyakarta Tahun Akademik 2013-2014 (Arraid, M. S, (2014); Implementasi Metode Permainan Edukatif Bahasa (Missing Lyrics) dalam Pembelajaran Bahasa Arab di Kelas VII MTs LB/A Yaketunis Yogyakarta Tahun Ajaran 2012/2013 (Melisa, 2014); Problematika Pembelajaran IPS pada Siswa Tunanetra di MTs Yaketunis Yogyakarta (Azet Nur Rahmawati, 2016); Studi Komparasi Tentang Keterampilan Melawat Dengan Tongkat Antara Siswa Tunanetra Yang Tinggal Di Rumah Dengan Yang Tinggal Di Asrama Di MTs Yaketunis Yogyakarta (Anita Yudhiastuti, 2016); Manajemen Sarana dan Prasarana Pendidikan dalam Meningkatkan Proses Pembelajaran di MTs Yaketunis Yogyakarta (Yulia Ayusanningtyas, 2017); Implementasi Pembelajaran Al-Qur'an Braille Pada Siswa Kelas 1 Di MTs Yayasan Kesejahteraan Tuna Netra Islam Yogyakarta Tahun 2010-2011 (Saefudin, 2018); Perilaku Siswa Tunanetra Pada Pembelajaran SKI Di MTs Yaketunis (Susilah, 2018); ; and many others studies. The above studies look from various points of view of educational components ranging from curriculum, learning strategies in various subjects, educational management, and so on. The research conducted by this writer looks more at the uniqueness of this madrasa administration. This madrasa provides special inclusive education for the blinds. As we know, the Ministry of Religion is not in charge of special institutions / schools (SLB). So MTs Yaketunis is a general education institution that provides education for children with special needs with visual impairments. Usually schools / madrasahs accept all types of children with special needs, but MTs Yaketunis only accepts blind children. This research, apart from looking at the special education service model for blind children from various regions in Indonesia, also looks at the existence of this madrasah in the social setting of the community in the city of Yogyakarta.

\section{Methodology}

This research was conducted with a qualitative approach. The research method used is descriptive qualitative method. This method is used to describe a phenomenon, events, and events that occur in the present. The data collection techniques used in this study were interview guides, documentation studies, and observations. Documentation studies are used to obtain secondary data. Meanwhile, the interviews were directed to all respondents such as officials of the Regional Office/Ministry of Religion of the City/District, heads of foundations/ head of madrasahs, supervisors, committees, parents of students, teachers, students and so on. Those interviewed are those who can be considered eligible to provide views and assessments of the provision of education for children with special needs in madrasa. Meanwhile, the observation method is used to observe important research objects that will enrich the research data. The data analysis technique used qualitative descriptive analysis. Descriptive analysis is used to fully explain the implementation of madrasas based on certain criteria/indicators. 


\section{Results and Discussion}

\section{Learning system}

Yaketunis students not only come from the city of Yogyakarta and its surroundings but from various regions in Indonesia including: Aceh, Medan, Padang, Palembang, Banten, Jakarta, Bandung, Surabaya, Mataram, Kupang, Ujung Pandang, Samarinda, Banjarmasin, Makassar, and other parts of Indonesia.

By considering the condition of students, since 1984 the Yaketunis issued a policy to homose students so that it can help reduce student difficulties in learning and the school can also control student learning. With assimilation, there is a continuity of learning programs in schools and in dormitories, so that the dormitory is a place of training after the child is in school. In addition, boarding schools are a suitable school choice for students who come from outside the region, because they have limited shuttle facilities.

Like other regular schools, MTs Yaketunis students start studying at 07.00 WIB until 13.30 WIB. Then from 14.00 WIB to 15.00 WIB they carried out extracurricular activities according to their choice. After that they just returned to the dormitory. Activities in the dormitory start after the congregational prayer Ashar.

The hostel, which is occupied by blind children, is an orphanage managed by the Yaketunis foundation. In this orphanage the children continue with various activities after returning from school. The daily activities of the orphanage children are organized under the name Yaketunis Foster Children Organization, ORMAKE (Yaketunis Dormitory Organization). The organization is under the auspices of the orphanage caregiver (dormitory father) who organizes all the activities of the orphanage to make it more lively, because by giving foster children the opportunity to make daily activities of the orphanage it is hoped that foster children will feel more ownership so that they are willing and fully self-aware to be active in enlivening activities that are is in the home.

\section{Curriculum}

The curriculum used by MTs Yaketunis is the same as the madrasa curriculum in general, namely the 2013 curriculum. This is because MTs Yaketunis is no longer an extraordinary madrasah but is now undergoing a transformation from an extraordinary madrasa to an inclusion school that is ready to accept students who experience retardation in various conditions. Therefore the curriculum used also follows the school curriculum in general, it's just that at MTs Yaketunis a number of subjects related to soft skills for the blind are added, such as: (1) Braille Reading Interest Improvement Program (PPMBB) for 1 (one) hour per week ; (2) Providing additional Qowa'idul Imla 'Subjects to improve braille reading and writing skills in learning Arabic; (3) Mobility Orientation (OM). This activity is specifically for students in grades VII and VIII to introduce students to every known and unknown environment safely, effectively, efficiently, flexible and independently. For roads with guiding blocks, it is very helpful for the mobility of the visually impaired, but for roads in villages or those where there is no guiding block, children need to be equipped with how to do their mobility. Also this activity also equips students to find out how to find fallen items; (4) Massage. This activity is to train students to have skills in massage.

The students were also given the skills to make salted eggs. Every 2 (two) weeks they finish (on Tuesday) they practice making salted eggs from the UGM faculty of animal husbandry. The process of making salted eggs takes 2 (two) weeks. They are also taught how to cook or bake. In this skill, blind children are asked by the teacher to buy ingredients or bake 
cakes at the market alone. This skill activity also trains blind children to be independent in mobility activities.

MTs Yaketunis students are students who have visual deficiencies but have the same needs as normal students, namely the need for knowledge that will be used as provisions for interacting with the community. Only their physical condition is different. In addition, MTs Yaketunis students are also treated the same in learning evaluation, namely taking the National Examination (UN) held by the government and also formative and summative test tests which are held based on joint decisions in the Ministry of Religion. The curriculum structure at MTs Yaketunis is the same as other MTs, only added to subjects related to disability and skills such as mobility orientation subjects and massage skills. For religious learning, plus Qowaid subjects, memorizing Alqur'an (optional subjects) and rhetoric da'wah.

In order to provide knowledge and prepare students with visual impairments to continue their education at the next level, curricular activities are held including: Foreign Language Learning (Arabic and English); Mastery of the Field of Study (USEK / UNAS); and Mastery of Arabic Braille (Qowa'idul lmla ') and Braille Qur'an, read and write the Braille Qur'an. Meanwhile, to provide practical skills and knowledge for blind students, extra-curricular lessons are held, including: art (music) which is done every Monday, Massage (massage) every Tuesday, memorizing the Qur'an every Wednesday and Thursday, Scouting every Friday, at, and Read and Write Braille (BTB) every Saturday. The extra-curricular activities are carried out after the learning activities, namely at 14.00 WIB, except for BTB activities every Saturday morning at $8 \mathrm{am}$. Other extra activities are sports such as table tennis, chess and goal ball). The sports equipment used by children with visual impairments is somewhat different from those used for alert children. For table tennis and goal ball using a ball that has a sound because children with visual impairments can know the direction of the ball from the source of the sound they hear.

\section{Learning methods}

Learning methods for children with disabilities are different from other children with special needs. Because they have limited vision, they can use braille for reading lessons. To read the Alquran, the Braille Alquran is available. However, other general subjects need teacher creativity. There are many methods used by teachers in learning blind children because of the unavailability of textbooks in braille. In general, the learning methods used by general subject teachers vary depending on the type of material being taught. One of the media that can be used is an android cellphone. Children learn through files that have been stored on their cellphones. Children open the file and listen then make a summary of what they hear. For students who do not have cell phones, usually the teacher dictates and the children take notes. Children can also learn by listening from active speakers.

For learning mathematics, one of the methods used is to draw something on the back for boys and draw on the table for female students. This method is to give a deep impression to students so that what was drawn can be drawn in the mind and the child will easily remember it. The actual method used depends on the material provided. For building materials, for example, the learning media used can be cubes, pyramids, triangles, tiles and so on. With the technique of feeling, it is hoped that blind children can understand the teacher's explanation regarding the material. However, there are also many difficulties experienced by mathematics teachers, especially for materials where there is no learning media. In algebra, for example, teachers have a little difficulty teaching the concept. Explanations accompanied by examples may be one 
strategy that can be used, for example in the problem of addition, subtraction or multiplication. Another difficulty was encountered with the problem of calculating the volume.

For science learning, the learning methods used also differ depending on the material provided. If the material is in the form of theory, the teacher can explain while dictating or the child can browse the internet via cellphone. Similar to science learning, social studies subjects as well as several other subjects also use almost the same method. However, because there are limitations in learning media, teachers must be creative in using their own learning methods. The important thing is how blind children can easily understand what is being taught by the teacher.

To overcome student burnout, there are some activities outside the classroom (outing class) such as in museums, recreational parks, playgrounds, river rafting, and so on. This activity is carried out when new students (class VII) attend the student orientation period (MOS) or also when the children are approaching exams so that they are fresher.

\section{The constraints faced by MTs Yaketunis}

According to the counseling guidance (BK) teacher, Siti Sa'adah, in general the difficulties in teaching were experienced by almost all teachers. To a lesser extent children with visual impairments experience mental instability. Sometimes children who are in a bad mood cannot be forced to study. Another problem is that the materials provided for children with visual impairment are exactly the same as for normal children, so that there are many obstacles faced by the teacher in learning. Textbooks needed by blind children are available because the books provided by the government are all for normal children. The foundation is also having difficulty printing textbooks in Braille due to the limited cost of facilities and personnel. Until now, there are no Braille textbooks available, so subject teachers must be creative in creating various learning media so that children can understand what is being taught. In addition, for skills lessons, the tools or facilities are not yet available so that teachers adjust skills learning with available or affordable tools such as making salted eggs, cooking skills, massage, and so on. Another problem is that what is taught in school is sometimes not supported by their parents at home. At school children are taught to be independent while their parents are at home often spoiling their children by reason of not having the heart or pity.

Another problem Yaketunis faced was the problem of limited space. In general, room facilities have not met the minimum standards. Only classrooms have been fulfilled, but for other rooms, such as the Science and Language laboratories, there are no facilities for sports. Sports activities such as goal ball, running with the raffia, throwing discs, and shooting are usually carried out in the Minggiran Yogyakarta field. Meanwhile, gymnastics and table tennis activities can be done at MTs Yaketunis yard.

In learning, the problem found is that there are students who have a disability. This requires a different strategy in handling because apart from suffering from blindness there are also other obstacles.

Limited funding is also a major problem because this MTs only relies on school operational assistance (BOS) funds amounting to 30 million rupiahs a year plus 50,000 rupiahs per month. Most of the parents of students have middle and lower economic class so that they are on average less able to afford child financing for school. For boarding fees students pay 50,000 rupiahs per month. With these limited funds, Yaketunis can only provide a small teacher honorarium.

The role of the government (Ministry of Religion) in advancing MTs Yaketunis has not yet been seen. MTs Yaketunis is still viewed like other madrasas. There has not been any special attention to the needs of children with visual impairments, especially in relation to learning 
facilities for children with visual impairments. Apart from BOS funds, space assistance was given recently for the construction of new classrooms. The Provincial Government of Yogyakarta has not yet paid attention to Yaketunis. There has never been any assistance from the local government to Yaketunis, both in terms of educational infrastructure, intensive teachers and improving teacher quality.

\section{Conclusion}

The education service model at MTs Yaketunis is almost the same as the boarding school / madrasa service model. The curriculum used is the same, namely the 2013 curriculum, but there are slight modifications. Education services for blind children at MTs Yaketunis are quite good and successful with all the existing limitations such as the absence of general subject books in Braille form, the availability of incomplete learning infrastructure, limited special tutor teachers, minimal funding, etc. The constraints that arise in the learning process do not hinder the creativity of teachers to improve the quality of their children education. The spirit of the teacher, patience, and sincerity of the teachers in educating children with special needs is one of the assets for the success of education. This is proven by the various achievements made by MTs Yaketunis students.

The government (Ministry of Religion) has not issued a regulation for inclusive education in madrasa, so the role of the government in advancing MTs Yaketunis as an inclusive madrasa has not been seen yet. There is no special treathment for this madrasa.

\section{REFERENCES}

[1] UU No 20 Tahun 2003 Tentang Sisdiknas Bab 4, Hak Dan Kewajiban Warga Negara, Pasal 5 Ayat 1 -3 [2] Pertuni. 2004. Persatuan Tunanetra Indonesia (Artikel). www.pertuni.org diunduh pada 28 Agustus 2017.

[3] Purwanto, H. (2015) Modul Pembelajaran : Pendidikan Anak Berkebutuhan Khusus, (UPI Bandung).

Tersedia di : file.upi.edu/Direktori/FPMIPA/PRODI._ILMU_KOMPUTER... Diakses Diakses : 24 Agustus 2019

[4] Bachri, S. (2010) Guru dan Anak Didik Dalam Interaksi Edukatif Suatu Pendekatan teoritis Psikologis. Jakarta : Rineka Cipta.

[5] PP No. 17 Tahun 2010 Tentang Pengelolaan Dan Penyelenggaraan Pendidikan Pasal 129 - 137

[6] Hallahan, D.p. \& Kauffman, J.m. (1991). Exceptional Children : Introduction to

Special Education. Virginia: Prentice hall International, Inc.

[7] Kirk, S.A. (1986) Pendidikan Anak Luar Biasa. Jakarta: DNIKS 